\title{
REDUCED ARBUSCULAR MYCORRHIZAL COLONIZATION IN TOMATO ETHYLENE MUTANTS
}

\author{
Agustin Zsögön ${ }^{1}$; Marcio Rodrigues Lambais²; Vagner Augusto Benedito ${ }^{3}$; Antonio Vargas \\ de Oliveira Figueira ${ }^{3}$; Lázaro Eustáquio Pereira Peres ${ }^{1 *}$ \\ ${ }^{1}$ USP/ESALQ - Depto. de Ciências Biológicas, C.P. 09 - 13418-900 - Piracicaba, SP - Brasil. \\ ${ }^{2}$ USP/ESALQ - Depto. de Ciência do Solo. \\ ${ }^{3}$ USP/CENA - Av. Centenário 303 - 13400-970 - Piracicaba, SP - Brasil. \\ *Corresponding author <lazaropp@esalq.usp.br>
}

\begin{abstract}
Plant hormones are likely key regulators of arbuscular mycorrhizae (AM) development. However, their roles in AM are not well known. Here mutants in five hormone classes introgressed in a single tomato (Lycopersicon esculentum Mill. Syn Solanum lycopersicum L.) background (cv. Micro-Tom) were used to determine their effects on AM development and the expression of defenserelated genes (chitinases and $\beta$-1,3-glucanases) in roots. Under low $\mathrm{P}$ conditions, mutant epinastic (epi) and Never ripe ( $\mathrm{Nr}$ ), ethylene overproducer and low sensitivity, respectively, had the intraradical colonization by Glomus clarum highly inhibited, as compared to the control Micro-Tom (MT). No significant alterations in fungal colonization were observed in mutants affecting other hormone classes. Under low P conditions, the steady state levels of transcripts encoding a class I basic chitinase (chi9) were higher in mycorrhizal epi and $\mathrm{Nr}$ mutant roots as compared to MT controls. In contrast the steady state levels of a class III acidic $\beta$-1,3-glucanase (TomPR-Q'a) transcripts in mycorrhizal epi mutant roots were significantly lower than in mycorrhizal MT roots. Root colonization in epi mutants was accompanied by several alterations in fungal morphology, as compared to root colonization in MT controls. The data suggest that ethylene may play an important role in controlling intraradical arbuscular mycorrhizal fungal growth.

Key words: Lycopersicon, Micro-Tom, defense-related genes, hormones, phosphate
\end{abstract}

\section{REDUZIDA FORMAÇÃO DE MICORRÍZAS ARBUSCULARES EM TOMATEIROS MUTANTES EMETILENO}

\begin{abstract}
RESUMO: Os hormônios vegetais são possíveis reguladores chave do desenvolvimento de micorrizas arbusculares (MAS). Contudo, seus papéis em MA são pouco conhecidos. No presente estudo, foram utilizados mutantes em cinco classes hormonais introgredidos em uma única cultivar (cv. MicroTom) de tomateiro (Lycopersicon esculentum Mill. Syn Solanum lycopersicum L.) para determinar seus efeitos no desenvolvimento de MA e expressão de genes relacionados à defesa (quitinases e $\beta$ 1,3-glucanases) em raízes. Sob condição de baixo P, os mutantes epinastic (epi) e Never ripe ( $\mathrm{Nr}$ ), os quais são super produtores e pouco sensíveis a etileno, respectivamente, tiveram a colonização intraradicular por Glomus clarum inibida quando comparada com o controle Micro-Tom (MT). Não se observou alterações significativas na colonização fúngica nos mutantes afetando outras classes hormonais. Sob condição de baixo $\mathrm{P}$, o nível de transcritos codificando uma quitinase básica de classe I (chi9) foi mais elevado em raízes micorrizadas dos mutantes epi e $\mathrm{Nr}$, quando comparado com o controle MT. Em contraste, o nível de transcritos de uma $\beta$-1,3-glucanase ácida da classe III (TomPR$\left.Q^{\prime} a\right)$ em raízes micorrizadas do mutante epi foi significativamente menor que em raízes micorrizadas de MT. A colonização de raízes no mutante epi foi acompanhada por várias alterações na morfologia fúngica, quando comparada com o controle MT. Os resultados sugerem que o etileno pode desempenhar um importante papel controlando o crescimento fúngico intra-radicular nas MAS.

Palavras-chave: Lycopersicon, Micro-Tom, genes relacionados à defesa, fosfato, hormônios
\end{abstract}

\section{INTRODUCTION}

It has been well documented that arbuscular mycorrhiza (AM) formation is highly modulated by phosphate $(\mathrm{P})$ concentration in the plants (Lambais,
2006; Javot et al., 2007). However, the molecular mechanisms by which P controls AM development are largely unknown. Lambais \& Mehdy (1995) proposed that $\mathrm{P}$ modulates the intraradical growth of arbuscular mycorrhizal fungi (AMF) through plant hormones, 
which are likely to play a key role in controlling the expression of defense-related genes. Reports on hormone dosages and exogenous applications related to AM development have been published, even though the roles of plant hormones in AM are not clear (Beyrle, 1995; Ludwig-Müller, 2000; Costa et al., 2000; Hause et al., 2002; Shaul-Keinan et al., 2002).

An alternative approach to overcome the uncertainties associated to hormone dosage and exogenous applications in the study of AM formation is the use of hormonal mutants. Since Arabidopsis thaliana, the wide used genetic model, is not able to develop AM, the Micro-Tom (MT) cultivar of tomato (Meissner et al., 1997) can be used as an alternative model to study AM development and signaling (DavidSchwartz et al., 2001). As Arabidopsis, MT has a small size, short life cycle and amenability for genetic manipulation (mutant and transgenic plants production). Here, tomato mutants with low sensitivity to auxin (diageotropica, Oh et al., 2006), cytokinin (bushy root, Pino-Nunes, 2005) and ethylene (Never ripe, Wikinson et al., 1995), as well as tomato mutants with high sensitivity to gibberellin (procera, Jones, 1987), low abscisic acid level (notabilis, Burbidge et al., 1999) and high ethylene production (epinastic, Barry et al., 2001) into the MT background were used to study the formation of AM. Using this mutant collection we shown that epinastic and Never ripe, two ethylene-related mutations, have significant inhibitory effects on root colonization by Glomus clarum under low P conditions, when compared to MT controls, and that the effect of ethylene may be associated to the control of defense-relate responses. No significant alterations in fungal colonization were observed in mutants affected in other hormonal classes.

\section{MATERIALAND METHODS}

\section{Plant and fungal materials}

Tomato (Lycopersicon esculentum Mill. Syn Solanum lycopersicum L.) mutants (Peres et al., 2005) with low sensitivity to auxin (diageotropica, Oh et al., 2006), cytokinin (bushy root, Pino-Nunes, 2005) and ethylene (Never ripe, Wikinson et al., 1995), as well as tomato mutants with high sensitivity to gibberellin (procera, Jones, 1987), low abscisic acid level (notabilis, Burbidge et al., 1999) and high ethylene production (epinastic, Barry et al., 2001) were obtained at the Tomato Genetic Research Center (University of California, Davis) and introgressed into the genetic model system cv Micro-Tom (MT), obtained at the Weizmann Institute of Science (Israel). The introgression of mutations into MT was performed as described previously (Lima et al., 2004). Briefly, after the first backcross generation (BC), plants were selfed to produce $\mathrm{BC} 1 \mathrm{~F} 2$ plants, which were screened for the mutations of interest and miniature size. This procedure was repeated until $\mathrm{BC} 3 \mathrm{~F} 2$. One of the mutations contributing to MT small size is $d w a r f$ (Lima et al., 2004; Marti et al., 2006), which leads to a reduction in brassinosteroid (BR) levels (Bishop et al., 1999). However, different from other tomato BR mutants, such as dumpy and curl-3 (Koka et al., 2000), the $d$ warf allele harbored by MT does not result in a drastic phenotype, but produces a miniaturized plant with a proportional reduction in all organs size (Meissner et al., 1997). At least another unknown mutation is responsible for MT reduced size (Lima et al., 2004), although it has been demonstrated that this cultivar is not GA deficient/insensitive (Marti et al., 2006).

Glomus clarum inoculum was multiplied in association with Brachiaria decumbens roots in pots containing sand and vermiculite as substrate and under greenhouse conditions.

\section{Experimental design and growth conditions}

Three experiments were performed to evaluate $\mathrm{AM}$ formation in tomato hormonal mutants introgressed into MT. The first experiment was set up to test the effect of the epinastic (epi) mutation, the second to test the effect of the notabilis (not) mutation, and the third to test the effect of Never ripe ( $\mathrm{Nr})$, diageotropica (dgt), procera (pro) and bushy root (brt) mutations on AMF root colonization. In all experiments, MT was used as the control. Surface-sterilized seeds from mutants and MT genotypes were germinated in boxes containing a mixture of commercial pot mix (Plantmax HT Eucatex, Brazil) and vermiculite (1:1, $\mathrm{v}: \mathrm{v})$, supplemented with $1 \mathrm{~g}$ NPK 10:10:10 and $4 \mathrm{~g}$ of lime per liter of substrate. Seedlings showing the first true leaves were transplanted into $350 \mathrm{~mL}$ capillary plastic pots filled with a mixture of autoclaved sand $\left(1 \mathrm{~h}, 120^{\circ} \mathrm{C}\right)$ and polystyrene irregular pellets $(1: 1$, v:v). Distilled water was supplied by capillarity. A mixture of soil, G. clarum spores, hyphae and roots infected by $B$. decumbens $(10 \mathrm{~g})$ was used as inoculum. Non-mycorrhizal control treatments were inoculated with a mixture of soil and non-mycorrhizal $B$. decumbens roots (10 g). Phosphate was supplied twice a week as $\mathrm{KH}_{2} \mathrm{PO}_{4}$ in solution to a final concentration of 4 or $40 \mathrm{mg} \mathrm{P} \mathrm{kg}{ }^{-1}$ substrate, for low and high $\mathrm{P}$ conditions, respectively (David-Schwartz et al., 2001). Treatments were arranged in fully randomized blocks, with eight replicate plants for mycorrhizal and three for non-mycorrhizal treatments. Plants were grown under greenhouse conditions. Harvest was performed 35 days after transplanting, before anthesis, and the upper third of root system was removed to evaluate 
intraradical fungal colonization. The remaining roots were immediately frozen in liquid $\mathrm{N}_{2}$ and stored at $80^{\circ} \mathrm{C}$ for molecular analyses. Shoots were dried to constant mass at $60^{\circ} \mathrm{C}$ and used for dry matter and phosphorus concentration determinations.

\section{Phosphorus concentration in shoots}

Dried shoots were ground to a fine powder and used for the determination of phosphorus concentration by spectrophotometry at $420 \mathrm{~nm}$, after nitroperchloric digestion (Malavolta et al., 1992).

\section{Intraradical fungal colonization}

Root sub-samples were fixed in FAA and stained with ink (QuInk, Parker, UK) and acetic acid solution according to Vierheilig et al. (1998), and the intraradical fungal growth determined using the intersection method (Giovannetti \& Mosse, 1980). Intraradical fungal growth was determined as the percentage of the total root length colonized by the AMF.

Roots of genotypes with significant alterations in colonization rate, as compared to MT controls, were cut in $1 \mathrm{~cm}$ fragments and examined under an Eclipse E800 microscope (Nikon, Japan) coupled to an Exwave HAD digital camera (Sony, Japan).

\section{Defense-related transcript accumulation analyses}

The steady state levels of transcripts encoding chi9 (class I chitinase), TomPR- $Q^{\prime} a$, (class III $\beta$ 1,3-glucanase) and TomPR-Q'b (class III $\beta$-1,3glucanase) in mycorrhizal roots of epinastic and Never ripe mutants, and MT control, grown under low $\mathrm{P}$ conditions, were determined using qRT-PCR analyses, and GAPDH (glyceraldehyde-3-phosphate dehydrogenase) as the constitutive control. Total RNA was extracted from frozen root samples using TRIzol Reagent (Invitrogen, São Paulo, Brazil). RNA quality was checked on $1.5 \%$ formaldehyde-agarose gel and quantification was performed spectrophotometricaly at 260 nm (SmartSpec 3000, BioRad, Hercules, CA). Total RNA was treated with DNase I (Fermentas Life Sciences, Ontario, Canada), and first-strand cDNA was synthesized using SuperScript II reverse transcriptase system (Invitrogen, São Paulo, Brazil). Specific prim- ers for target (chi9, TomPR- $Q^{\prime} a$, and TomPR- $Q^{\prime} b$ ) and constitutive control $(G A P D H)$ genes were designed based on conserved regions of sequences deposited in the NCBI (http://www.ncbi.nlm.nih.gov/) or TIGR (http://www.tigr.org/) databases (Table 1), using Primer3 (http://www-genome.wi.mit.edu/ cgi-bin/primer/ primer3_www.cgi).qRT-PCR analyses were carried out using a Rotor-Gene 3000 thermocycler (Corbett, Australia). PCR was performed in $10 \mu \mathrm{L}$ of Taq-polymerase buffer solution containing $50 \mathrm{ng}$ first-strand cDNA templates, $0.8 \mu \mathrm{M}$ of each primer and SYBR-green master mix (Applied Biosystems, São Paulo, Brazil). All samples were amplified in triplicate under the following conditions: $95^{\circ} \mathrm{C}$ for $10 \mathrm{~min}$, followed by 45 cycles of $95^{\circ} \mathrm{C}$ for $20 \mathrm{~s}$ and $60^{\circ} \mathrm{C}$ for $45 \mathrm{~s}$. The products for each primer set were subjected to melt-curve analysis using the thermocycler manufacturer's software (Corbett, Australia). The transcript abundance ratio of the target genes to the reference gene was determined as described by Pfaffl (2001).

\section{Statistical analyses}

The data were analyzed by one-way ANOVA and means were compared using Student's $t$-test $(P<0.05)$. Colonization rates were normalized prior to statistical analyses.

\section{RESULTS}

\section{Intraradical fungal colonization}

In all experiments, the intraradical fungal colonization in MT tomato was significantly reduced under high $\mathrm{P}$ conditions as compared to low $\mathrm{P}$ conditions $(P<0.05$, Figure 1$)$. The ethylene-overproducing mutant epi, under low $\mathrm{P}$ conditions, showed a significant 3.1-fold reduction in AMF intraradical colonization when compared to the MT control $(P<0.05$, Figure 1a).

ABA-deficient mutant not, which synthesizes less than $50 \%$ of the normal ABA levels (Tal, 1966), showed no significant alterations in the rates of intraradical colonization, as compared to the MT controls, neither at low nor at high $\mathrm{P}$ conditions $(P>0.05$, Figure 1b).

Table 1 - Sequence of the primers used for the quantitative real-time RT-PCR assays and expected size of generated amplicons.

\begin{tabular}{|c|c|c|c|}
\hline Gene & Primers & Amplicon size (pb) & GenBank entry \\
\hline chi9 & $\begin{array}{l}\text { 5'- GCT TTT GCT GTC TGC CTG T -3' } \\
\text { 5'- GCC CTT CCT CCA GTA GTT TC - } 3^{\prime}\end{array}$ & 196 & Z15140 \\
\hline TomPR-Q'a & $\begin{array}{l}\text { 5'- TAA GGA ACA TTC AAA CCG CA -3' } \\
\text { 5'- CCA ACC RCT CTC YGA TAC AA -3' }\end{array}$ & 122 & X74905 \\
\hline TomPR- $Q^{\prime} b$ & $\begin{array}{l}\text { 5'- TGA GAA ACA TTC AGA ACG CG -3' } \\
\text { 5'- CCA ACC RCT CTC YGA TAC AA -3' }\end{array}$ & 383 & X74906 \\
\hline
\end{tabular}


In the ethylene-insensitive mutant $\mathrm{Nr}$, the intraradical colonization rates were 1.3 and 1.4 -fold lower than in the MT control, under low and high $\mathrm{P}$ conditions, respectively $(P<0.05$, Figure $1 \mathrm{c})$. In the pro, dgt and brt mutants, the differences in intraradical fungal colonization either under low or high $\mathrm{P}$ conditions, as compared to the MT control, were not significant $(P>0.05$, Figure 1c).

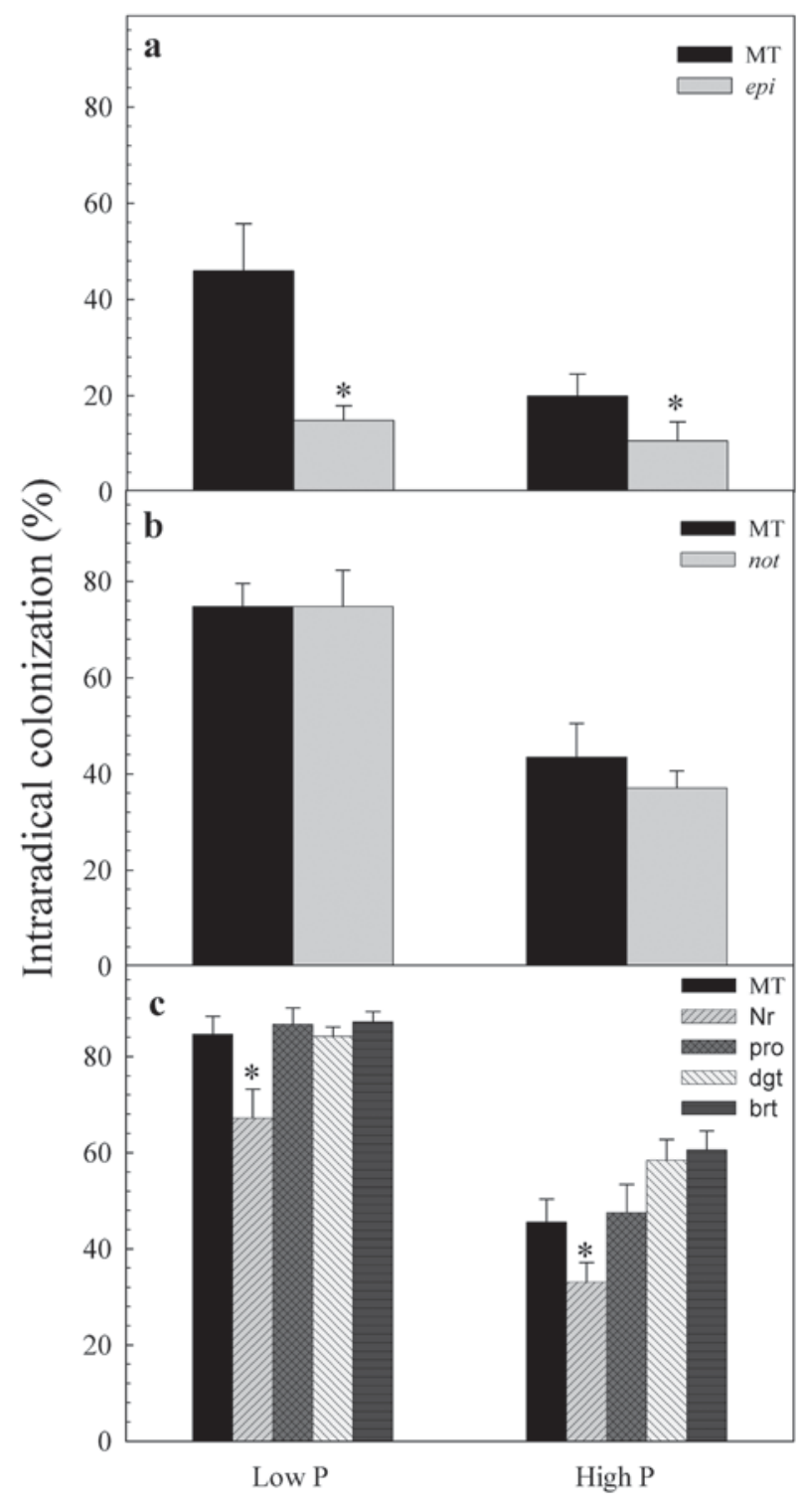

Figure 1 - Intraradical colonization of tomato roots by Glomus clarum under low and high P conditions. a) MicroTom (MT) and epinastic (epi) mutant. b) MT and notabilis (not) mutant roots. c) MT, Never ripe ( $\mathrm{Nr}$ ), procera (pro), diageotropica (dgt) and bushy root (brt) mutants. Data represent the means of 8 repetitions \pm SE. Within the same P condition, means marked with asterisk are significantly different from the MT control (Student's t test, $P<0.05$ ).
Mycorrhizal roots of the ethylene mutants $\mathrm{Nr}$ and epi as well as the MT controls were examined using phase-contrast microscopy. The fungal growth pattern within the roots was indicative of Arum-type colonization, with abundant arbuscules and vesicles (Figure 2a). Typical appressorium development was detected on MT roots (Figure 2b). However, several morphological alterations, such as abundant external hyphae without intraradical growth (Figure 2c), swollen hypha (Figure 2d) and limited growth within the cortex (Figure 2e), where observed in epi mutant roots. Reduced number of vesicles, which were abundant in MT (Figure 2a), as well as high incidence of hyphal coils within cortical cells (Figure 2f) was observed in the epi mutant. In spite of the reduction in root colonization, fungal morphology in $\mathrm{Nr}$ mutant and MT control was indistinguishable (data not shown).

\section{Defense-related transcript accumulation}

Considering the roles of ethylene in plant defense responses, the steady-sate levels of transcripts encoding a basic chitinase, a basic and an acidic isoform of $\beta$-1,3-glucanase regulated by ethylene and likely involved in AM regulation (Lambais \& Mehdy, 1995), were determined using qRT-PCR in mycorrhizal roots of the mutants epi and $\mathrm{Nr}$ and the MT control when grown under low $\mathrm{P}$ conditions.

The steady-state levels of chi9 transcripts in mycorrhizal roots of epi mutants were approximately 4.1-fold higher than in mycorrhizal roots of the MT control $(P<0.05$, Figure 3a) whereas the steady-sate levels of TomPR-Q'a transcripts were approximately 5.6-fold lower in epi mycorrhizal roots than in MT mycorrhizal roots $(P<0.05$, Figure $3 \mathrm{~b})$, and the steady state levels of TomPR-Q'b in epi mycorrhizal roots were not statistically different from MT mycorrhizal roots $(P>0.05$, Figure $3 \mathrm{c})$.

For $\mathrm{Nr}$ mycorrhizal roots grown under low $\mathrm{P}$, the steady state levels of chi9 transcripts were approximately 44-fold higher than in mycorrhizal roots of MT $(P<0.05$, Figure $3 \mathrm{~d})$, whereas the steady state levels of TomPR-Q' $a$ and TomPR- $Q^{\prime} b$ transcripts in $\mathrm{Nr}$ mycorrhizal roots, although higher, were not significantly different from the steady state levels of transcripts observed in mycorrhizal roots of MT $(P>0.05$, Figure 3e-f).

\section{Shoot $P$ concentration}

In order to assess the impact of the epi and $N r$ mutations for $\mathrm{P}$ uptake and translocation to the shoots, $\mathrm{P}$ concentrations in the shoots of epi, $\mathrm{Nr}$ and MT, grown under low and high P conditions were determined. At low $\mathrm{P}$ conditions, shoot $\mathrm{P}$ concentrations in epi and $\mathrm{Nr}$ non-mycorrhizal mutant plants were lower than in non-mycorrhizal MT $(P<0.05$, Figure 

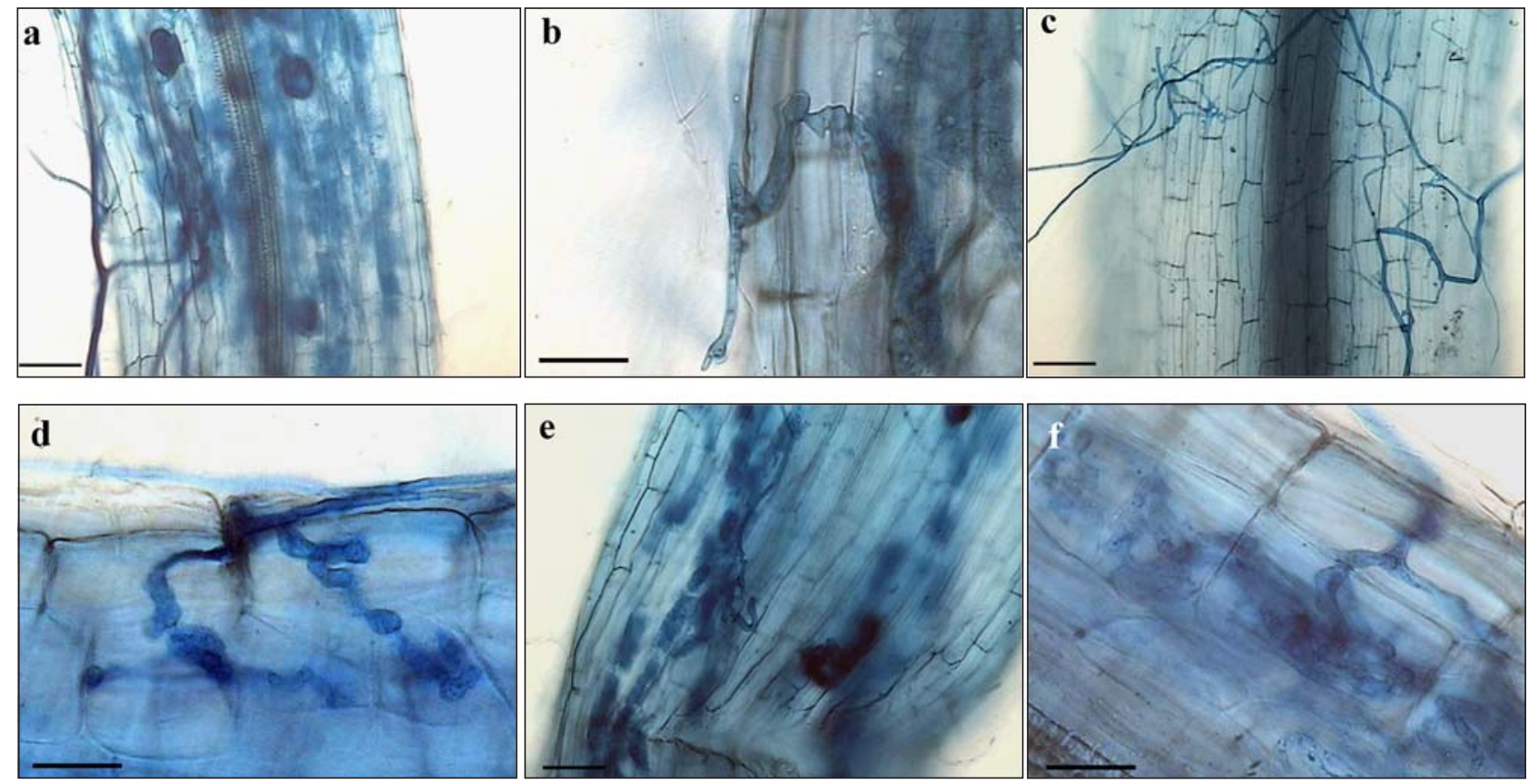

Figure 2 - Phase contrast micrographs of tomato roots colonized by Glomus clarum. a) Micro-Tom (MT) root showing extensive colonization with arbuscules and vesicles. Scale bar $=100 \mu \mathrm{m}$. b) Typical appressorium on the surface of MT root. Scale bar $=25 \mu \mathrm{m}$. c) Abundant external hypha with no intraradical colonization on epinastic mutant (epi) root. Scale bar $=100 \mu \mathrm{m}$. d) Abnormal appressoria on epi root. Scale bar $=25 \mu \mathrm{m}$. e) Limited infection unit in epi root. Scale bar $=100 \mu \mathrm{m}$. f) Apressorium and intracellular coiled hypha in epi mutant root. Scale bar $=25 \mu \mathrm{m}$.

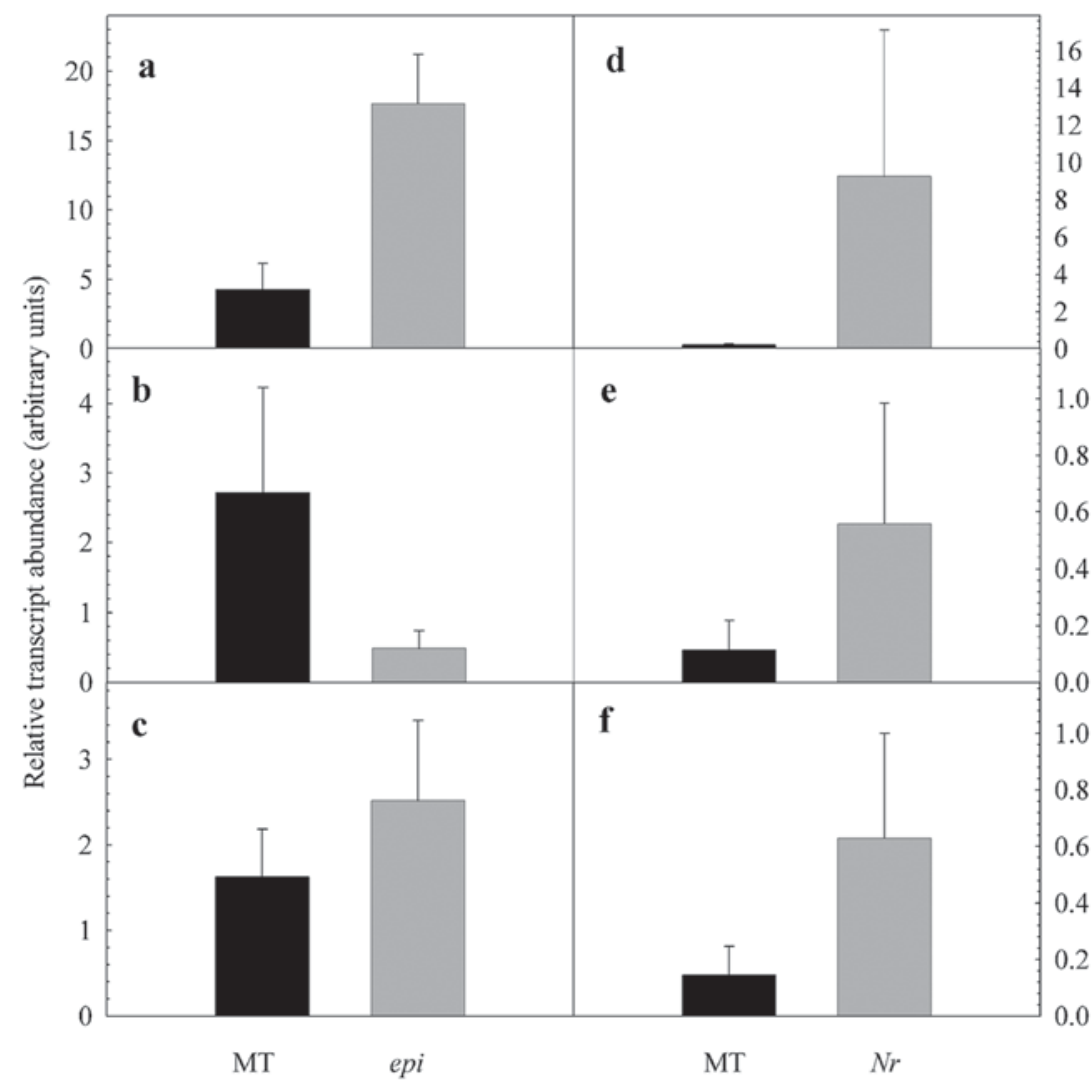

Figure 3 - Defense-related transcript abundance in mycorrhizal tomato roots grown under low $\mathrm{P}$ conditions relative to non-mycorrhizal controls. a, d) Class I basic chitinase (chi9). b, e) Class III acid $\beta$-1,3-glucanase (TomPR-Q'a). (c, f) Basic $\beta$-1,3-glucanase $\left(T o m P R-Q^{\prime} b\right)$. Data are the means of 3 repetitions $\pm \mathrm{SE}$. 
$4 \mathrm{a}, \mathrm{c})$, whereas there were no differences $(P>0.05)$ between non-mycorrhizal genotypes when at high $\mathrm{P}$ condition (Figure 4b,d).

Shoot $\mathrm{P}$ concentration in mycorrhizal epi mutants were lower than in mycorrhizal MT at low $\mathrm{P}$ conditions $(P<0.05$, Figure $4 \mathrm{a})$, whereas at high $\mathrm{P}$ conditions there were no differences $(P>0.05$, Figure $4 b)$. Shoot $\mathrm{P}$ concentration in mycorrhizal $\mathrm{Nr}$ mutants and mycorrhizal MT either at low or high $\mathrm{P}$ conditions were not significantly different $(P>0.05$, Figure $4 \mathrm{c}$, d).

\section{DISCUSSION}

In this paper a preliminary assessment of the effects of five classes of tomato hormonal mutants on AM infection under low and high $\mathrm{P}$ conditions was performed. Among the mutants tested, the intraradical colonization by G. clarum was significantly reduced in both ethylene mutants (epi and $\mathrm{Nr}$ ) mostly when plants were grown under low $\mathrm{P}$ conditions. The epi mutant is constitutively activated in a subset of ethylene responses, including the expression of the ethylene-induced gene chi9, encoding a class I basic chitinase (Barry et al., 2001), whereas the $N r$ mutant is insensitive to ethylene (Wikinson et al., 1995). The reduction of AM formation in different ethylene contexts (low sensitivity and high production) is consistent with early suggestions that although this hormone is highly inhibitory for colonization (Azcón-Aguilar et al., 1981; Ishii et al., 1996; Geil et al., 2001), at low concentration it may also stimulate the fungal growth (Ishii et al., 1996).

Ethylene can act as a signal for the induction of a wide range of physiological processes, such as seed germination, senescence, epinasty, abscission and fruit ripening as well as plant defense responses (Abeles et al., 1992). A common event behind some of these processes is the activation of hydrolytic enzymes such as polygalacturonases, glucanases and chitinases. Among the hydrolases induced by ethylene, chitinases and $\beta$-1,3-glucanases may have important roles in controlling the intraradical growth of AMF (Lambais \& Mehdy, 1995). Since hydrolytic enzymes may either help AMF penetration or prevent colonization by degrading the plant or fungal cell walls, the negative effect of both ethylene-overproducing (epi) and-insensitive $(\mathrm{Nr})$ might be somewhat linked to the activity of these enzyme or other delicate balance of substances induced by this plant hormone in the roots (Lambais \& Mehdy, 1995).

Transient increases in the activities of specific chitinases and $\beta$-1,3-glucanases have been reported to occur in mycorrhizal roots as compared to non-mycorrhizal controls (Lambais \& Mehdy, 1993; Spanu et al., 1989; Vierheilig et al., 1994). In addition, accumulation of transcripts encoding chitinases and $\beta-1,3-$ glucanases in cells containing arbuscules and their vi-

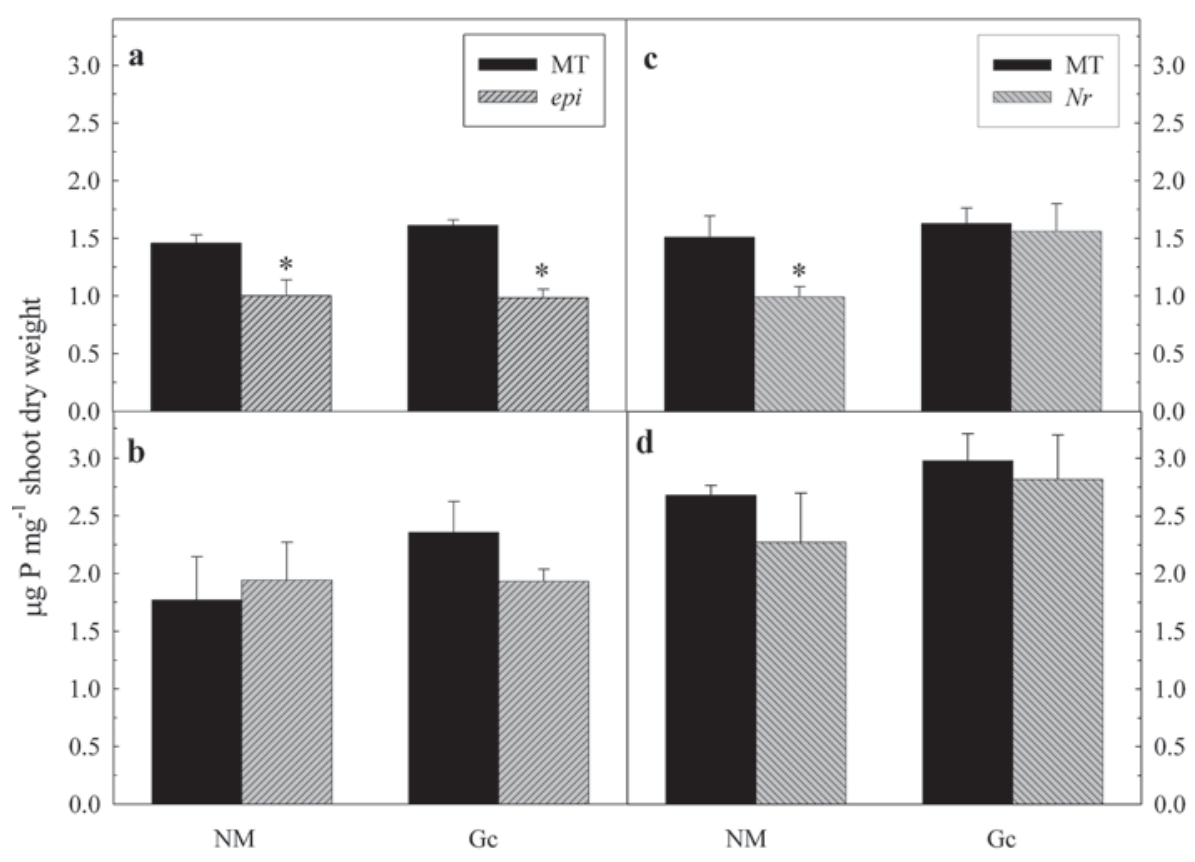

Figure 4 - Phosphorus concentration in the shoots of non-mycorrhizal (NM) and mycorrhizal (Gc) Micro-Tom (MT), Never ripe (Nr) and epinastic (epi) genotypes grown under low $(\mathrm{a}, \mathrm{c})$ or high $(\mathrm{b}, \mathrm{d}) \mathrm{P}$ conditions. Data are the means of 8 repetitions $\pm \mathrm{SE}$ (mycorrhizal plants) or the means of 3 repetitions $\pm \mathrm{SE}$ (non-mycorrhizal plants). Within the same $\mathrm{P}$ condition and inoculation treatment, means marked with asterisk are significantly different from the MT control (Student's $\mathrm{t}$ test, $P<0.05$ ). 
cinity (Lambais \& Mehdy, 1998), and suppression of a basic chitinase transcript accumulation in bean mycorrhizal roots, as compared to non-mycorrhizal controls, have been reported (Lambais \& Mehdy, 1993). In general, under high $\mathrm{P}$ conditions, the expression of these genes is induced or their suppression is attenuated (Lambais, 2000). However, a causal relationship between chitinases or $\beta$-1,3-glucanases and AM development has not been demonstrated so far, even though transgenic tobacco plants overexpressing a basic chitinase isoform do not show reduced levels of intraradical fungal growth when compared to nontransgenic controls (Vierheilig et al., 1995). In our preliminary study, under low P conditions, the steady-state levels of chi9 was greatly induced in the roots of epi and $\mathrm{Nr}$ mycorrhizal mutants, as compared to MT, suggesting that basic chitinases may have an important role in controlling intraradical fungal growth, and that the regulation of chi9 expression is dependent on other signals than ethylene. The results on the expression of $\beta$-1,3-glucanases are inconclusive. Reduced transcript accumulation of the acid isoform in epi mutant and increased transcript accumulation, although not significant, of the basic and acidic isoforms in $\mathrm{Nr}$ mutant suggest a complex regulatory mechanism that may depend on multiple signal molecules acting systemically as well as at the cell level in mycorrhizal roots (Lambais \& Mehdy, 1995).

Under low P conditions, $\mathrm{P}$ concentration in the shoots of mycorrhizal epi mutant plants were lower than in mycorrhizal MT controls, whereas the P concentration in the shoots of mycorrhizal $\mathrm{Nr}$ mutants was not significantly different from the MT control, suggesting that the effect on intraradical fungal growth was not related to the $\mathrm{P}$ concentration in the shoots. In addition, $G$. clarum growth in epi mutant roots under low $\mathrm{P}$ conditions was impaired as compared to the growth in MT roots. These data suggest that an early step in the signal transduction necessary for intraradical accommodation was not functional in epi mutant or that the intraradical fungal growth was actively inhibited in this mutant. The AM development in epi resembles that in reduced mycorrhizal colonization $(\mathrm{rmc})$ tomato mutant, as described by Barker et al. (1998). Since epi and rms are not allelic, as they map on chromosomes 4 (Barry et al., 2001) and 8 (Larkan et al., 2007), respectively, it would be interesting to investigate the relationship between these two mutants. Further studies are also necessary to determine whether the infection or the colonization process is inhibited in epi mutants.

Based in this study, there is no evidence for a direct involvement of the other mutation tested in the intraradical fungal colonization, under low or high $\mathrm{P}$ conditions. However, these results do not rule out other effects of ABA, auxins, gibberellins and cytokinins on the regulation of the symbiose. For example, the discovery that cytokinins are negative regulators of $\mathrm{P}$ starvation responses (Franco-Zorrilla et al., 2002) implies that this hormone may indirectly influence AM development in some situations. In the case of ABA-deficient mutant notabilis, results are in conflict with the recent report of reduced AM formation in the ABAdeficient tomato mutant sitiens (Herrera-Medina et al., 2007). Since ABA deficiency causes an elevation on ethylene production (Sharp et al., 2000), HerreraMedina et al. (2007) provided evidence for a role of ethylene in AM formation using an exogenous inhibitor of this hormone action. The notabilis mutation used here is less drastic than sitiens, which presents a phenotype more characteristic of a severe ABA deficiency (e.g. viviparous seed germination) and also of ethylene overproduction (e.g. leaf epinasty). Whether the difference in severity of ABA deficiency in sitiens and notabilis mutants is related to their differences in AM development remains to be determined. Furthemore, the availability of mutants in different hormone classes in the same Micro-Tom background will provide for double mutant analyses in order to clarify the relative contribution of ethylene and ABA for AM formation.

We have observed that the characteristic wilty phenotype of the ABA-deficient mutant not is delayed in mycorrhizal plants under water stress conditions, as compared to non-mycorrhizal plants (data not shown). This genotype represents a null mutation for the gene LeNCED1, encoding a 9-cis-epoxycarotenoid dioxygenase (NCED) involved in the oxidative cleavage of carotenoids (Burbidge et al., 1999). NCED is also a key enzyme in the biosynthesis of strigolactones (Humphrey \& Beale, 2006), which have been shown to induce AMF hypha branching (Akiyama et al., 2005). However, whether the not tomato mutants used in this study are impaired in the biosynthesis of strigolactones has not been determined. Since the levels of intraradical fungal growth in the not mutant and MT were not significantly different, it can be speculated that either strigolactones are not essential for AM development or NCEDs other than the one encoded by the NOT gene are involved in the production of strigolactones.

In summary, ethylene imbalances in tomato have a significant effect on intraradical AMF colonization mostly under low P conditions. Future work should address how the change in ethylene content/ sensitivity in opposite directions would lead to a similar effect in AM formation. Additionally, it was shown that a collection of tomato mutants in a single tomato 
background represented by MT could be of great value to study AM development under different edaphic conditions. The availability of large populations of MT insertional mutants (Meissner et al., 2000; Mathews et al., 2003) and ESTs databases specific for this cultivar (Yano et al., 2005) provide convenient tools for further studies on the molecular mechanisms controlling AM development.

\section{ACKNOWLEDGEMENTS}

To Dr. Roger Chetelat (Tomato Genetics Resource Center, Davis, USA) and Dr. A. Levy (Weizmann Institute of Science, Israel) for the supplying parental hormone mutants and MT seeds, respectively. This project was supported by FAPESP (02/ 00329-8) and CNPq (475494/03-2). MRL and LEPP were supported by CNPq and AZ by CAPES fellowships.

\section{REFERENCES}

ABELES, F.B.; MORGAN, P.W.; SALTVEIT, M.E. Ethylene in plant biology. 2.ed. San Diego, CA: Academic Press, 1992. $414 p$.

AKIYAMA, K.; MATSUZAKI, K.; HAYASHI, H. Plant sesquiterpenes induce hyphal branching in arbuscular mycorrhizal fungi. Nature, v.435, p.824-827, 2005.

AZCÓN-AGUILAR, C.; RODRIGUEZ-NAVARRO, D.N.; BAREA, J.M. Effects of ethrel on the formation and responses to VA mycorrhiza in Medicago and Triticum. Plant and Soil, v.60, p.461-468, 1981 .

BARKER, S.J.; STUMMER, B.; GAO, L.; DISPAIN, I.; O'CONNOR, P.J.; SMITH, S.E. A mutant in Lycopersicon esculentum Mill. with highly reduced VA mycorrhizal colonization: isolation and preliminary characterization. Plant Journal, v.15, p.791-797, 1998.

BARRY, C.S.; FOX, E.A.; YEN, H.; LEE, S.; YING, T.; GRIERSON, D.; GIOVANNONI, J. Analysis of the ethylene response in the epinastic mutant of tomato. Plant Physiology, v.127, p.5866,2001

BEYRLE, H. The role of phytohormones in the function and biology of mycorrhizas. In: VARMA, A.; HOCK, B. (Ed.). Mycorrhiza: structure, function, molecular biology and biotechnology. Berlin: Springer-Verlag, 1995. p.365-390.

BISHOP, G.J.; NOMURA, T.; YOKOTA, T.; HARRISON, K.; NOGUCHI, T.; FUJIOKA, S.; TAKATSUTO, S.; JONES, J.D.G.; KAMIYA, Y. The tomato DWARF enzyme catalyses C-6 oxidation in brassinosteroid biosynthesis. Proceedings of the National Academy of Sciences of the USA, v.96, p.1761$1766,1999$.

BURBIDGE, A.; GRIEVE, T.M.; JACKSON, A.; THOMPSON, A.; MCCARTY, D.R.; TAYLOR, I.B. Characterization of the ABAdeficient tomato mutant notabilis and its relationship with maize Vp14. Plant Journal, v.17, p.427-431, 1999.

COSTA, H.S.; RIOS-RUIZ, W.F.; LAMBAIS, M.R. Salicylic acid inhibits arbuscular mycorrhyzae formation and changes chitinase and $\beta-1,3$-glucanase expression in bean roots. Scientia Agricola, v.57, p.19-25, 2000.

DAVID-SCHWARTZ, D.; BADANI, H.; SMADAR, W.; LEVY, A.A.; GALILI, G.; KAPULNIK, Y. Identification of a novel genetically controlled step in mycorrhizal colonization: plant resistance to infection by fungal spores but not extra-radical hyphae. Plant Journal, v.27, p.561-569, 2001.
FRANCO-ZORRILLA, J.M.; MARTIN, A.C.; SOLANO, R.; RUBIO, V.; LEYVA, A.; PAZ-ARES, J. Mutations at CRE1 impair cytokinin-induced repression of phosphate starvation responses in Arabidopsis. Plant Journal, v.32, p.353-360, 2002.

GEIL, R.D.; PETERSON, R.L.; GUINEL, F.C. Morphological alterations of pea (Pisum sativum cv. Sparkle) arbuscular mycorrhizas as a result of exogenous ethylene treatment. Mycorrhiza, v.11, p.137-143, 2001.

GIOVANETTI, M.; MOSSE, B. An evaluation of techniques for measuring vesicular arbuscular mycorrhizal infection in roots. New Phytologist, v.84, p.489-500, 1980.

HAUSE, B.; MAIER, W.; MIERSCH, O.; KRAMELL, R.; STRACK, D. Induction of jasmonate biosynthesis in arbuscular mycorrhizal barley roots. Plant Physiology, v.130, p.1213-1220, 2002.

HERRERA-MEDINA, M.J.; STEINKELLNER, S.; VIERHEILIG, H.; BOTE, J.A.O.; GARRIDO, J.M.G. Abscisic acid determines arbuscule development and functionality in the tomato arbuscular mycorrhiza. New Phytologist, v.175, p.554-564, 2007.

HUMPHREY, A.J.; BEALE, M.H. Strigol: biogenesis and physiological activity. Phytochemistry, v.7, p.636-640, 2006.

ISHII, T.; SHRESTHA, Y.H.; MATSUMOTO, I.; KADOYA, K. Effect of ethylene on the growth of vesicular-arbuscular mycorrhizal fungi and on the mycorrhizal formation of trifoliate orange roots. Journal of the Japanese Society for Horticultural Science, v.65, p.525-592, 1996.

JAVOT, H.; PUMPLIN, N.; HARRISON, M.J. Phosphate in the arbuscular mycorrhizal symbiosis: transport properties and regulatory roles. Plant Cell and Environment, v.30, p.310$322,2007$.

JONES, M.G. Gibberellins and the procera mutant of tomato. Planta, v.172, p.280-284, 1987.

KOKA, C.V.; CERNY, R.E.; GARDNER, R.G.; NOGUCHI, T.; FUJIOKA, S.; TAKATSUTO, S.; YOSHIDA, S.; CLOUSE, S.D. A putative role for the tomato genes DUMPY and CURL-3 in brassinosteroid biosynthesis and response. Plant Physiology, v.122, p.85-98, 2000

LAMBAIS, M.R. Regulation of plant defense-related genes in arbuscular mycorrhizae. In: PODILA, G.K.; DOUDS, D.D. (Ed.). Current Advances in Mycorrhizae Research. St Paul: American Phytopathological Society Press, 2000. p.46-60.

LAMBAIS, M.R. Unraveling the signaling and signal transduction mechanisms controlling arbuscular mycorrhiza development. Scientia Agricola, v.63, p.405-413, 2006.

LAMBAIS, M.R.; MEHDY, M.C. Suppression of endochitinase, b1-3-endoglucanase, and chalcone isomerase expression in bean vesicular-arbuscular mycorrhizal roots under different soil phosphate conditions. Molecular Plant-Microbe Interactions, v.6, p.75-83, 1993.

LAMBAIS, M.R.; MEHDY, M.C. Differential expression of defenserelated genes in arbuscular mycorrhiza. Canadian Journal of Botany, v.73, p.S533-S540, 1995. Supplement 1.

LAMBAIS, M.R.; MEHDY, M.C. Spatial distribution of chitinases and b-1-3-glucanase transcripts in bean arbuscular mycorrhizal roots under low and high soil phosphate conditions. New Phytologist, v.140, p.33-42, 1998.

LARKAN, N.J.; SMITH, S.E.; BARKER S.J. Position of the reduced mycorrhizal colonization $(R m c)$ locus on the tomato genome map. Mycorrhiza, v.17, p.311-318, 2007.

LIMA, J.E.; CARVALHO, R.F.; TULMANN NETO, A.; FIGUEIRA, A.; PERES, L.E.P. Micro-MsK: a tomato genotype with miniature size, short life cycle and improved in vitro shoot regeneration. Plant Science, v.167, p.753-757, 2004.

LUDWIG-MÜLLER, J. Hormonal balance in plants during colonization by mycorrhizal fungi. In: KAPULNIK, Y.; DOUDS, D.D. (Ed.). Arbuscular mycorrhizas: physiology and function. Dordrecht: Kluwer Academic Publishers, 2000. p.263-285.

MALAVOLTA, E.; VITTI, G.C.; OLIVEIRA, A.S. Avaliação do estado nutricional das plantas: princípios e aplicações. 2.ed. Piracicaba: Associação Brasileira para Pesquisa da Potassa e do Fosfato, 1992. 319p. 
MARTI, E.; GISBERT, C.; BISHOP, G.J.; DIXON, M.S.; GARCIAMARTINEZ, J.L. Genetic and physiological characterization of tomato cv. Micro-Tom. Journal of Experimental Botany, v.57, p.2037-2047, 2006.

MATHEWS, H.; CLENDENNEN, S.K.; CALDWELL, C.G.; LIU, X.L.; CONNORS, K.; MATHEIS, N.; SCHUSTER, D.K.; MENASCO, D.J.; WAGONER, W.; LIGHTNER, J.; WAGNER, D.R. Activation tagging in tomato identifies a transcriptional regulator of anthocyanin biosynthesis, modification, and transport. Plant Cell, v.15, p.1689-1703, 2003.

MEISSNER, R.; JACOBSON, Y.; MELAMED, S.; LEVYATUV, S.; SHALEV, G.; ASHRI, A.; ELKIND, Y.; LEVY, A. A new model system for tomato genetics. Plant Journal, v.12, p.14651472, 1997.

MEISSNER, R.; CHAGUE, V.; ZHU, Q.; EMMANUEL, E.; ELKIND, Y.; LEVY, A.A. A high throughput system for transposon tagging and promoter trapping in tomato. Plant Journal, v.22, p.265-274, 2000.

OH, K.C.; IVANCHENKO, M.G.; WHITE, T.J.; LOMAX, T.L. The diageotropica gene of tomato encodes a cyclophilin: a novel player in auxin signaling. Planta, v.224, p.133-144, 2006.

PERES, L.E.P.; CARVALHO, R.F.; ZSÖGÖN, A.; ZAMBRANO, O.D.B.; ROBLES, W.G.R.; TAVARES, S. Grafting of tomato mutants onto potato rootstocks: an approach to study leafderived signaling on tuberrization. Plant Science, v.169, p.680688,2005 .

PFAFFL, M.W. A new mathematical model for relative quantification in real-time RT-PCR. Nucleic Acids Research, v.29, p.20022007, 2001.

PINO-NUNES, L.E. Uso de mutantes com alterações no balanço auxina/citocinina no estudo da competência para regeneração in vitro em micro-tomateiro (Lycopersicon esculentum cv Micro-Tom). Piracicaba:USP/ESALQ, 2005. 73p. (Thesis MSc).

SHARP, R.E.; LENOBLE, M.E.; ELSE, M.A.; THORNE, E.T.; GHERARDI, F. Endogenous ABA maintains growth in tomato independently of effects on plant water balance: evidence for an interaction with ethylene. Journal of Experimental Botany, v.51, p.1575-1584, 2000.
SHAUL-KEINAN, O.; GADKAR, V.; GINZBERG, I.; GRÜNZWEIG, J.; CHET, I.; ELAD, Y.; WININGER, S.; BELAUSOV, E.; ESHED, Y.; ARTZMON, N.; BEN-TAL, Y.; KAPULNIK, Y. Hormone concentrations in tobacco roots change during arbuscular colonization with Glomus intraradices. New Phytologist, v.154, p.501-507, 2002.

SPANU, P.; BOLLER, T.; LUDWIG, A.; WIEMKEN, A.; FACCIO, A.: BONFANTE-FASOLO, P. Chitinase in roots of mycorrhizal Allium porrum - regulation and localization. Planta, v.177, p.447-455, 1989.

TAL, M. Abnormal stomatal behavior in wilty mutants of tomato. Plant Physiology, v.41, p.1387-1391, 1966.

VIERHEILIG, H.; ALT, M.; MOHR, U.; BOLLER, T.; WIEMKEN, A. Ethylene biosynthesis and activities of chitinase and $\beta-1,3-$ glucanase in the roots of host and non-host plants of vesiculararbuscular fungi after inoculation with Glomus mosseae. Journal of Plant Physiology, v.143, p.337-343, 1994.

VIERHEILIG, H.; ALT, M.; LANGE, J.; GUT-RELLA, M.; WIEMKEN, A.; BOLLER, T. Colonization of transgenic tobacco constitutively expressing pathogenesis-related proteins by vesicular-arbuscular mycorrhizal fungus Glomus moseae. Applied and Environmental Microbiology, v.61, p.30313034, 1995.

VIERHEILIG, H.; COUGHLAN, A.P.; WYSS, U.; PICHÉ, Y. Ink and vinegar, a simple staining technique for arbuscularmycorrhizal fungi. Applied and Environmental Microbiology, v.64, p.5004-5007, 1998.

WIKINSON, J.Q.; LANAHAN, M.B.; YEN, H-C.; GIOVANNONI, J.J.; KLEE, H.J. An ethylene-inducible component of signal transduction encoded by Never-ripe. Science, v.270, p.1807$1809,1995$.

YANO, K.; WATANABE, M.; YAMAMOTO, N.; MAEDA, F.; TSUGANE, T.; SHIBATA, D. Expressed sequence tags (EST) database of a miniature tomato cultivar, Micro-Tom. Plant Cell Physiology, v.46, p.S139, 2005.

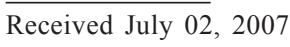

Accepted December 17, 2007 